DOI: $10.22616 /$ REEP.2020.055

\title{
Learning Motivation, Involvement in the Study Process and Formation of Supervisor Professional Identity for Supervision Students in Latvia
}

\author{
Maija Zakrizevska-Belogrudova ${ }^{1}$ Dr.psych; Anna Sevcenkova ${ }^{2}$ Mg.sc.admin. \\ RISEBA University of Applied Sciences, Latvia \\ maija.zakrizevska@riseba.lv${ }^{1}$; anna.sevcenkova@gmail.com²
}

\begin{abstract}
The research purpose was to study the formation of a supervisor's professional identity in context of study motivation and involvement in the learning process. In total, 54 students who were at that time acquiring supervisor profession were surveyed. The participants of the study took part in surveys listed below: Questionnaire on demographic data (created by the authors); Questionnaire on motivation types and involvement, MES-UC (Motivation Engagement Scale - University/College); Questionnaire for supervisors (modified after Professional Identity Scale in Counselling (PISC)). Summarizing the results of the study, the authors conclude that there is a statistically significant correlation between motivation, involvement in the learning process and professional identity of supervisors. The results show that there is a statistically significant negative correlation between the negative motivation scale "Anxiety" and the supervisor's professional identity scale "Knowledge about the profession". Also, results show that the $2^{\text {nd }}$ year students have a statistically significant correlation between the positive engagement scales "Task (study) management", "Persistence" and the supervisor's professional identity Scale "Philosophy of the Profession, Supervisor Competence and Roles". In addition, the results show that there is correlation between the negative involvement scale "Disengagement" and the supervisor's professional identity scale "Engagement in professional societies and activities". Since the results of the obtained data from the study show a relatively unconvincing connection that motivation and involvement in the learning process is a determining factor in the identification and development of the supervisor's professional identity, so the authors recommend continuing the study with a larger sample size (for example, at the Baltic level) or to develop a longitudinal study on the basis of the existing study to identify the internal (personal) and external factors that influence the awareness and formation of the supervisor's professional identity during the study process at the university.
\end{abstract}

Keywords: learning motivation, involvement in learning process, supervisor, professional identity.

\section{Introduction}

As suggested by the number of members in the Register of Certified Supervisors on the website of the Latvian Association of Supervisors, which is increasing every year, the approved standard for the profession of a supervisor and the events held for supervisors every year, supervision is developing very rapidly as a profession. In Latvia, a supervisor is a specialist who has acquired the Master's degree and the qualification of a supervisor in addition to the basic qualification. Opportunities for studying supervision have emerged relatively recently, in year 2014, and, even though its popularity is growing, it means that the number of qualified specialists is comparatively low but is increasing every year. The professional identity of the specialists in this profession, the fundament for which is laid already within the process of studies, is developing along with the new area of activity.

Considering that the profession is comparatively new, the professional identity of a supervisor is a new field of research in Latvia, with a small number of research studies. Until now, no research has been conducted into the factors which influence and facilitate positive awareness and development of the professional identity of a supervisor. One of the possible influencing factors suggested by the authors of the project is the positive correlation between the students' motivation for learning and engagement in the study process and the development of the professional identity of a supervisor. There are practically no research studies into the correlation between the students' motivation for learning and engagement in the study process and the development of the professional identity of a supervisor in Latvia. Therefore, it is essential to study it in order to ascertain the development of the professional identity of supervisors specifically in the process of studies.

Highlighting the internal and external types of motivation, the influence of motivation and engagement in the learning achievements has been researched by many scientists (Cokley, 2003; Pintrich, Zusho, 2002; Ryan, Deci, 2000; 2002; Deci, Ryan, 2008; Wigfield, Eccles, 2002; Martin, 2016; Wasityastuti 
et al., 2018). The researchers share a common opinion that the internal motivation is determined by high engagement in the process of studies which is targeted at learning achievements, feeling interest in and satisfaction with what has actually been achieved. The external motivation, in its turn, implies avoidance of punishment or negative consequences or willingness to receive an award. Professional identity, in its turn, includes: definition of one's own profession; conformity of the personal traits in a professional environment; integration of theoretical orientations and methodological approaches which matches the professional's own personal values and views; the professional ethics of a consultant, participation in professional organisations and feeling proud of the chosen profession (Adams et al., 2006; Ashforth et al., 2007; Vignoles et al., 2006; Roberts et al., 2005; Gibson, Dollarhide, Moss, 2010; Ashforth, 2001; Moss, Gibson, Dollarhide 2014).

The aim of this study is to research the association of the types of learning motivation of the Latvian students of the Master's Degree Programme in Supervision with the engagement in the process of learning and the professional identity of a supervisor during learning.

\section{Methodology}

Research questions: 1) Are there any differences / correlations in the learning motivation and engagement in the process of studies among the students of supervision? 2) Are there statistically significant differences in the self-evaluation of the professional identity of a supervisor between the supervision students of years 1 and 2? 3) Is there statistically significant correlation between the motivation for learning and engagement in the process of studies and the professional identity of a supervisor? 4) Is there a statistically significant correlation between the motivation and engagement scales and the supervisor professional identity scales among the students of year 2 ?

The strategy of a quantitative study has been selected for the research study, with the use of a demographic data survey and two surveys and summarisation and analysis of the primary data. The research study was conducted from 5th March 2018 until 10th April 2018.

Participants: Out of the 74 Latvian students studying supervision at the time of the research study, 54 students of supervision from the supervision study programmes of the Latvian institutions of higher education (RISEBA University of Applied Sciences, Riga Stradins University and Latvian Christian Academy) participated in the research study voluntarily. By the margin of error (7\%), the accuracy of the sample data is satisfactory. The respondents were between 24 and 46 years of age, including 46 women and 8 men.

\section{Instrumentarium:}

1. The motivation type and engagement questionnaire, MES-UC (Martin, 2016). The Australian researcher A.J. Martin (Martin, 2016) developed a Motivation and Engagement Scale (MES) for university/college students to measure the students' learning motivation and engagement in the process of studies. It may be used either individually or in a group. The MES - UC includes 11 subscales: Positive dimensions of motivation: the student's self-belief, learning focus, valuing the university. Positive dimensions of engagement: persistence, planning, task (study) management. Negative dimensions of motivation: anxiety, failure avoidance, uncertain control. Negative dimensions of engagement: self-sabotage, disengagement. The survey consists of 44 statements regarding a student's motivation and engagement in the study process which are to be rated on the Likert Scale of 1 (disagree entirely) to 7 (agree entirely).

2. The supervisor questionnaire adapted based on the Supervisor Questionnaire (Vaivade-Kalnmeiere, Mārtinsone, L,evina, 2016). Before the survey was adapted and modified based from the Professional Identity Scale in Counseling published in 2015 (Woo, Henfield, 2015) and developed to raise the issue of professional identity in the profession of a supervisor, and it measures the professional identity of a supervisor. The survey comprises 6 scales: the philosophy of the profession, competences and roles of supervisors, knowledge about the profession, engagement in professional associations and activities, representation and protection of the profession, personal professional growth and development, teaching the profession. It consists of 39 statements regarding the professional identity of a supervisor which need to be rated on the Likert scale of 1 (disagree entirely) to 6 (agree entirely).

Study procedure: the questionnaires to all of the year 1 students of the Supervision study programmes in the Latvian institutions of higher education were given during the classes, with the most convenient 
time being coordinated with the heads of the programmes and the lecturers. The questionnaires to the students of year 2 were sent out electronically via the website webropool.com. Data processing methods: the methods of descriptive statistics and the methods of inferential statistics were used for the processing of the data. The statistical analysis was carried out using IBM SPSS 23.0 statistical data processing software. Study restrictions: the study restrictions are associated with an insufficient volume of the study sample. Additional studies need to be conducted to research the issue with a larger study sample.

\section{Results and Discussion}

The Cronbach's alpha was calculated to evaluate whether the results obtained on the Motivation and Engagement Scale (MES-UC) are credible as well as whether the statements included in the scales are mutually consistent. The Cronbach's alpha obtained for the entire survey indicates good reliability and mutual consistency of the items $(\alpha=0.761)$. The determination of Cronbach's alpha coefficients for each of the scales leads to a conclusion that the scales have good internal consistency (Cronbach's alpha $\alpha=0.71-0.786$ ), which suggests good reliability of the results. The Cronbach's alpha was calculated to evaluate whether the results obtained from the Supervisor Professional Identity Survey are credible as well as whether the statements included in the scales are mutually consistent. The Cronbach's alpha obtained for the entire survey indicates high reliability and mutual consistency of the items $(\alpha=0.749)$. The determination of Cronbach's alpha coefficients for each of the scales leads to a conclusion that the scales have good internal consistency (Cronbach's alpha $\alpha=0.639-0.797$ ), which suggests that the results are reliable.

The normal distribution of the data for the sample studied in the research study was verified using the nonparametric Kolmogorov-Smirnov criterion, corrected by Lilliefors. It is concluded after the processing of the data that the empirical distribution of the data does not correspond to the normal distribution (at Sig. $<=0.05$, the data distribution statistically significantly differs from the normal distribution).

\section{Analysis of Questionnaire MES-UC results}

The results of the median indicators show that positive motivation is more typical among the respondents and includes such factors as Learning Focus $(M=86)$; Valuing $(M=85)$ and Self-belief $(M=74)$. As indicated by such factors as Persistence $(M=76)$; Task Management $(M=76)$ and Planning $(M=72)$, high positive engagement in the study process is typical among the respondents.

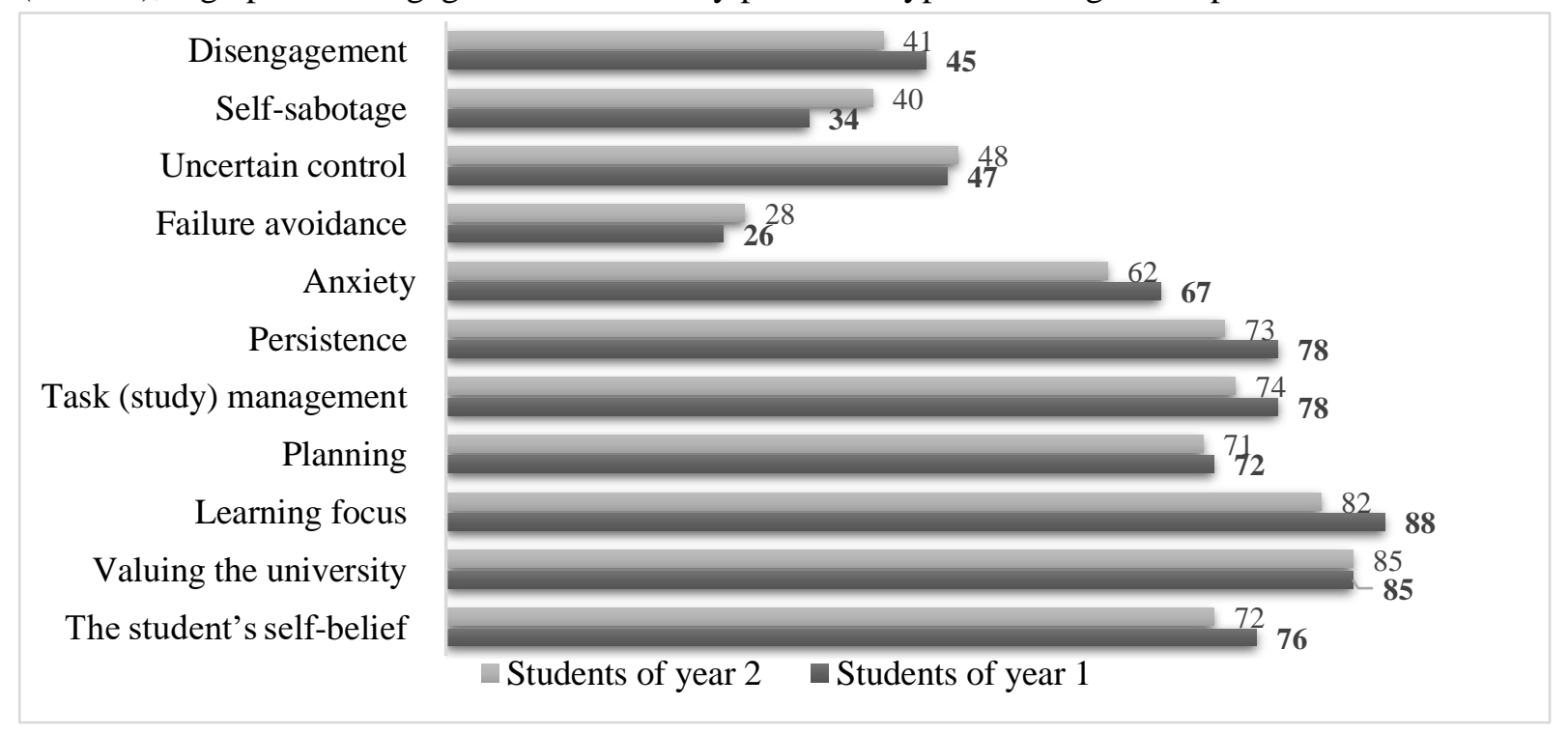

Figure 1. Average of motivational and engagement variables for motivation and engagement scales

(MES-UC) in supervision students of years 1 and 2.

Negative motivation among the respondents manifests primarily as Anxiety $(M=65)$ and Uncertain Control $(M=47)$. Negative engagement in the study process is not typical among the respondents (Disengagement $(M=37)$; Self-sabotage $(M=36))$. The evaluation of the results obtained for the $1^{\text {st }}$ 
and $2^{\text {nd }}$ year students of supervision shows, in its turn, that year 1 students have higher positive motivation and engagement (Self-belief; Learning Focus; Task Management; Persistence) than the year 2 students. The year 2 students, in their turn, have higher negative motivation and engagement (Failure Avoidance; Uncertain Control; Self-sabotage; Disengagement) than the year 1 students. The anxiety factor is more typical among the 1st year students than among the students of year 2 (Figure 1).

Table 1

The Mann-Whitney U-test values for motivation and engagement in supervision students of years 1 and 2

\begin{tabular}{lccc|c}
\hline \multirow{2}{*}{$\begin{array}{c}\text { Motivation and } \\
\text { engagement scales }\end{array}$} & Mann-Whitney & \multirow{2}{*}{ Significance } & \multicolumn{2}{c}{ Average Rank Value } \\
\cline { 4 - 5 } & $\mathbf{U}$ & & Students of year 1 & Students of year 2 \\
\hline The student's self-belief & 256.50 & 0.165 & 29.67 & 23.50 \\
Valuing the university & 340.50 & 0.884 & 27.27 & 27.92 \\
Learning focus & 245.50 & 0.112 & 29.99 & 22.92 \\
Planning & 325.50 & 0.898 & 27.70 & 27.13 \\
Task (study) management & 312.00 & 0.708 & 28.09 & 26.42 \\
Persistence & 281.50 & 0.363 & 28.96 & 24.82 \\
Anxiety & 259.00 & 0.181 & 29.60 & 23.63 \\
Failure avoidance & 358.50 & 0.634 & 26.76 & 28.87 \\
Uncertain control & 336.50 & 0.942 & 27.39 & 27.71 \\
Self-sabotage & 399.50 & 0.222 & 25.59 & 31.03 \\
Disengagement & 399.00 & 0.227 & 25.60 & 31.00 \\
\hline
\end{tabular}

Since, generally, the motivation and engagement scales do not correspond to the normal distribution, non-parametric methods have been used to determine the differences in the motivation and engagement results among the supervision students of years 1 and 2, by determining the Mann-Whitney $U$ test values. The obtained results reveal no statistically significant differences based on the Mann-Whitney U-test values on the motivation and engagement scales among the supervision students of years 1 and 2 (Table 1). The calculation of the Spearman's rank correlation coefficient was used for the analysis of the correlation between the motivation and engagement scales. The obtained results reveal that there is statistically significant positive correlation link between the positive motivation and positive engagement scales: Self-belief and Task Management; Self-belief and Persistence; Valuing and Task Management; Valuing and Persistence; Learning Focus and Task Management; Learning Focus and Persistence.

Table 2

Spearman's rank correlation coefficients $\left(r_{s}\right)$ for the motivation and engagement scales

\begin{tabular}{|c|c|c|c|c|c|c|}
\hline \multicolumn{2}{|c|}{ Scales } & \multirow{2}{*}{$\begin{array}{c}\text { Planning } \\
0.088\end{array}$} & \multirow{2}{*}{$\begin{array}{c}\text { Task (study) } \\
\text { management }\end{array}$} & \multirow{2}{*}{$\begin{array}{c}\text { Persistence } \\
0.352 * *\end{array}$} & \multirow{2}{*}{$\begin{array}{c}\begin{array}{c}\text { Self- } \\
\text { sabotage }\end{array} \\
0.109\end{array}$} & \multirow{2}{*}{$\begin{array}{c}\begin{array}{c}\text { Disenga- } \\
\text { gement }\end{array} \\
-0.194 \\
\end{array}$} \\
\hline The student's & $r_{s}$ & & & & & \\
\hline self-belief & Significance & 0.528 & 0.003 & 0.009 & 0.432 & 0.160 \\
\hline \multirow{2}{*}{$\begin{array}{l}\text { Valuing the } \\
\text { university }\end{array}$} & $r_{s}$ & 0.157 & $0.408 * *$ & $0.507 * *$ & -0.151 & $-0.285^{*}$ \\
\hline & Significance & 0.256 & 0.002 & 0.000 & 0.277 & 0.036 \\
\hline \multirow{2}{*}{$\begin{array}{l}\text { Learning } \\
\text { focus }\end{array}$} & $r_{s}$ & 0.192 & $0.467 * *$ & $0.621 * *$ & $-0.368 * *$ & -0.263 \\
\hline & Significance & 0.165 & 0.000 & 0.000 & 0.006 & 0.055 \\
\hline \multirow[t]{2}{*}{ Anxiety } & $r_{s}$ & $0.325^{*}$ & 0.019 & $0.295^{*}$ & 0.021 & -0.110 \\
\hline & Significance & 0.017 & 0.889 & 0.031 & 0.880 & 0.427 \\
\hline \multirow{2}{*}{$\begin{array}{l}\text { Failure } \\
\text { avoidance }\end{array}$} & $r_{s}$ & 0.026 & 0.022 & -0.058 & $0.451 * *$ & $0.375 * *$ \\
\hline & Significance & 0.854 & 0.875 & 0.679 & 0.001 & 0.005 \\
\hline \multirow{2}{*}{$\begin{array}{l}\text { Uncertain } \\
\text { control }\end{array}$} & $r_{s}$ & -0.051 & -0.108 & 0.075 & $0.509 * *$ & $0.417 * *$ \\
\hline & Significance & 0.713 & 0.437 & 0.588 & 0.000 & 0.002 \\
\hline
\end{tabular}

** Correlation is significant at the 0.01 level (2-tailed)

* Correlation is significant at the 0.05 level (2-tailed) 
There is a negative correlation link between the positive motivation scale Learning Focus and the negative engagement scale Self-sabotage. There is a correlation link between the negative motivation scale Anxiety and the positive engagement scale Planning. There is a correlation link between the negative motivation scale Anxiety and the positive engagement scale Persistence. There is a correlation link between the negative motivation scale Uncertain Control and the negative engagement scale Self-sabotage. There is a correlation link between the negative motivation scale Uncertain Control and the negative engagement scale Disengagement (Table 2).

\section{Analysis of Supervisor Professional Identity Survey Results}

The obtained results in the diagram of the median results show the following typical supervisor professional identity scales: Philosophy of Profession, Supervisor Competences and Roles and Knowledge about the Profession (Figure 2).

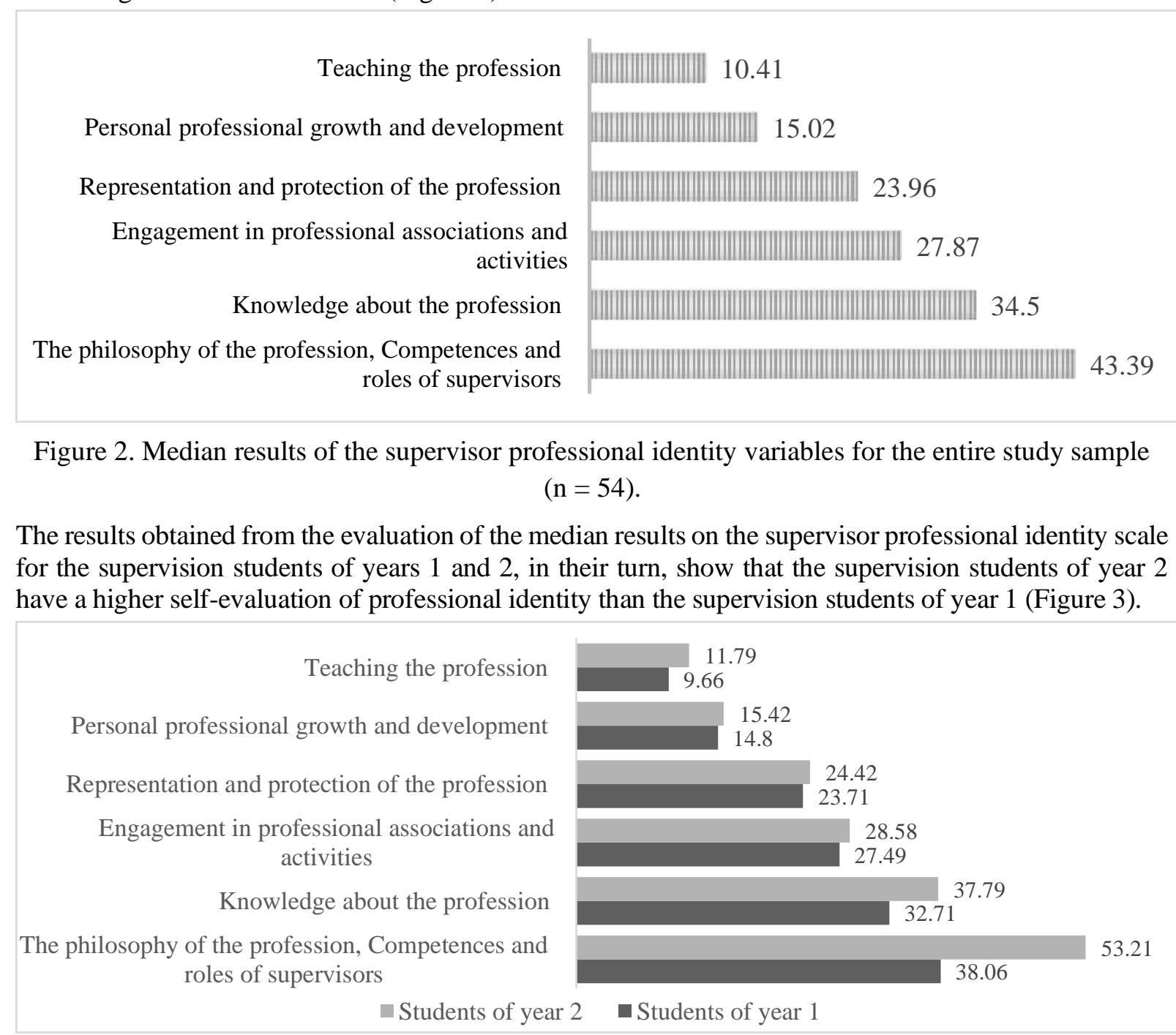

Figure 3. Median results of the supervisor professional identity variables in year $1(n=35)$ and year 2 $(\mathrm{n}=19)$ students of supervision.

The Mann-Whitney U-test was used to determine the differences between the supervision students of years 1 and 2. The obtained results show that there are statistically significant differences on the "Philosophy of Profession, Supervisor Competence and Roles" scale where the results of the year 2 supervision students are higher than those of the year 1 supervision students. The results also show statistically significant differences on the "Knowledge About Profession" scale where the results of the year 2 supervision students are higher than those of the year 1 supervision students. It should also be noted that there are statistically 
significant differences on the "Teaching the Profession" scale where the results of the year 2 supervision students are higher than those of the year 1 supervision students (Table 3).

Table 3

The Mann-Whitney U-test values on supervisor professional identity scales for supervision students of years 1 and 2

\begin{tabular}{lccccc}
\hline \multicolumn{1}{c}{ Supervisor professional identity scales } & $\begin{array}{c}\text { Mann- } \\
\text { Whitney }\end{array}$ & Significance & \multicolumn{2}{c}{ Average Rank Value } \\
\hline & U & & $\begin{array}{c}\text { Students } \\
\text { of year 1 }\end{array}$ & $\begin{array}{c}\text { Students } \\
\text { of year 2 }\end{array}$ \\
\hline $\begin{array}{l}\text { The philosophy of the profession, competences and } \\
\text { roles of supervisors }\end{array}$ & 110.50 & $\mathbf{0 . 0 0 0}$ & 21.16 & 39.18 \\
\hline Engagement in professional associations and activities & 284.00 & 0.378 & 26.11 & 30.05 \\
\hline Knowledge about the profession & 188.50 & $\mathbf{0 . 0 0 9}$ & 23.39 & 35.08 \\
\hline $\begin{array}{l}\text { Representation and protection of the profession } \\
\text { Personal professional growth and development }\end{array}$ & 317.00 & 0.778 & 27.06 & 28.32 \\
\hline Teaching the profession & 291.00 & 0.446 & 26.31 & 29.68 \\
\hline
\end{tabular}

The calculation of the Spearman's rank correlation coefficient was used for the calculation of the correlation between the motivation and engagement scales and the supervisor professional identity scales. It was concluded that there is a statistically significant correlation link between the variables "Anxiety" and "Knowledge About Profession" (Table 4).

Table 4

Correlation analysis: learning motivation and engagement in the process of studies and the professional identity of a supervisor, statistical significance (p) of Spearman's rank correlation coefficients

\begin{tabular}{|c|c|c|c|c|c|c|}
\hline Scales & $\begin{array}{l}\text { The } \\
\text { philosophy } \\
\text { of the } \\
\text { profession, } \\
\text { competences } \\
\text { and roles of } \\
\text { supervisors }\end{array}$ & $\begin{array}{l}\text { Knowledge } \\
\text { about the } \\
\text { profession }\end{array}$ & $\begin{array}{c}\text { Engagement } \\
\text { in } \\
\text { professional } \\
\text { associations } \\
\text { and activities }\end{array}$ & $\begin{array}{l}\text { Representation } \\
\text { and protection } \\
\text { of the profession }\end{array}$ & $\begin{array}{c}\text { Personal } \\
\text { professional } \\
\text { growth and } \\
\text { development }\end{array}$ & $\begin{array}{c}\text { Teaching } \\
\text { the } \\
\text { profession }\end{array}$ \\
\hline $\begin{array}{l}\text { The student's } \\
\text { self-belief }\end{array}$ & 0.759 & 0.934 & 0.195 & 0.489 & 0.784 & 0.076 \\
\hline $\begin{array}{l}\text { Valuing the } \\
\text { university }\end{array}$ & 0.883 & 0.287 & 0.123 & 0.832 & 0.861 & 0.241 \\
\hline Learning focus & 0.644 & 0.741 & 0.238 & 0.921 & 0.639 & 0.699 \\
\hline Planning & 0.452 & 0.909 & 0.728 & 0.892 & 0.775 & 0.571 \\
\hline $\begin{array}{l}\text { Task (study) } \\
\text { management }\end{array}$ & 0.718 & 0.905 & 0.844 & 0.410 & 0.630 & 0.722 \\
\hline Persistence & 0.956 & 0.189 & 0.296 & 0.570 & 0.836 & 0.484 \\
\hline Anxiety & 0.658 & 0.026 & 0.282 & 0.678 & 0.310 & 0.629 \\
\hline $\begin{array}{l}\text { Failure } \\
\text { avoidance }\end{array}$ & 0.954 & 0.742 & 0.437 & 0.158 & 0.393 & 0.982 \\
\hline Uncertain control & 0.815 & 0.968 & 0.388 & 0.618 & 0.515 & 0.482 \\
\hline Self-sabotage & 0.193 & 0.232 & 0.125 & 0.317 & 0.193 & 0.168 \\
\hline Disengagement & 0.642 & 0.685 & 0.402 & 0.761 & 0.133 & 0.367 \\
\hline
\end{tabular}

Additionally, non-linear regression analysis was carried out to determine the pattern of the changes in the resultative feature based on the changes in the value of the factorial feature. Linear, square and third power models were considered, the determination coefficients and the statistical significance of the models were calculated. Correlation diagram with regression curves for variables "Anxiety" "Knowledge About Profession". The linear model is statistically significant (determination coefficient $R^{2}=0.110, p=0.014$ ). This shows that the students' acquisition of knowledge and understanding of the profession increase as the levels of anxiety decrease (Table 5). 
Table 5

Non-linear regression analysis

\begin{tabular}{lc|c|c|c|c|c|c|c|c}
\hline \multirow{2}{*}{ Equation } & \multicolumn{5}{c|}{ Model Summary } & \multicolumn{5}{c}{ Parameter Estimates } \\
\cline { 2 - 11 } & R Square & F & $\mathbf{d f}_{\mathbf{1}}$ & $\mathbf{d f}_{\mathbf{2}}$ & Sig. & Constant & $\mathbf{b}_{\mathbf{1}}$ & $\mathbf{b}_{\mathbf{2}}$ & $\mathbf{b}_{3}$ \\
\hline Linear & 0.110 & 6.432 & 1 & 52 & $\mathbf{0 . 0 1 4}$ & 87.646 & -0.656 & & \\
Quadratic & 0.111 & 3.179 & 2 & 51 & 0.050 & 82.302 & -0.308 & -0.005 & \\
Cubic & 0.112 & 2.093 & 3 & 50 & 0.113 & 93.472 & -1.642 & 0.043 & -0.001 \\
\hline
\end{tabular}

The independent variable is "Knowledge About Profession"

Dependent Variable is "Anxiety"

The analysis of the demographic data reveals that the students primarily associate their supervision studies with self-improvement, professional development, and willingness to work with people. The students acknowledge that being a supervisor is a profession which has a potential and will be necessary in numerous professional areas. Most of the supervision students (93\%) are not associate members of the professional associations; likewise, most of the supervision students $(65 \%)$ do not attend supervision on supervision; $70 \%$ of the students of supervision do not attend events (seminars, conferences) associated with supervision; outside their studies, the students $(61 \%)$ have practically no communication with any practising supervisors, and this is suggestive of the process of development of the professional identity.

\section{Conclusions}

Although no statistically significant differences were identified, the median rank indicators led to conclusions that year 1 students have higher levels of positive learning motivation and engagement in the process of studies that the year 2 students. Negative motivation and engagement (Failure Avoidance; Self-sabotage; Non-engagement; Uncertain Control), in their turn, are more typical among the year 2 students. The results also show that there are significant positive correlations between positive learning motivation and positive engagement in the process of studies. Also, learning focus lowers if the student prefers other things, feels helpless and unwilling to engage in the process of studies. As the feeling of anxiety increases, the student develops passive attitude towards their studies and work performance.

In the self-evaluation of the professional identity of a supervisor, the supervision students of years 1 and 2 have statistically significant differences on the scales "Philosophy of Profession, Supervisor Competences and Roles"; "Knowledge About Profession" and "Teaching the Profession", where the year 2 supervision students have higher results than the supervision students of year 1 . These results of the study have much in common with the conclusions drawn from research studies conducted by other authors, namely, that the sense of the professional identity of supervisors starts to develop gradually along with the acquisition of the academic and practical knowledge. It is also concluded that there is a statistically significant correlation link between the variables "Anxiety" and "Knowledge About Profession". Lower levels of students' nervousness and anxiety in the process of studies assure higher levels of understanding of the binding laws in the profession of a supervisor, the associations, and other facts associated with the profession.

The results of the study suggest that professional identity is in the development process and that a large part of the students primarily associate their supervision studies with self-improvement, professional development, willingness to work with people, potentially without fully realising the very nature of the profession.

The authors of the research study believe that the initiated research should be continued by widening the basis for the empirical study, covering the students who study supervision in Latvia and students of supervision in other countries (on the level of the Baltic States, for example) because the data show only the total of 74 supervision students in Latvia, of which 54 took part in the study. Furthermore, it is necessary to additionally find out what internal (personal) or external factors facilitate awareness, development and improvement of learning motivation, engagement in the process of studies, and the professional identity of a supervisor.

\section{Bibliography}

1. Adams K., Hean S., Sturgis P., Clark J.M. (2006). Investigating the factors influencing professional identity of first-year health and social care students. Learning in Health and Social Care, 5(2), 55-68. doi: $10.1111 / \mathrm{j} .1473-6861.2006 .00119 . x$ 
2. Ashforth B.E. (2001). Role Transitions in Organizational Life: An Identity-Based Perspective. Mahwah, N.J.: Lawrence Erlbaum Associates

3. Ashforth B.E., Kreiner G., Clark M., Fugate M. (2007). Normalizing dirty work: Managerial tactics for countering occupational taint. Academy of Management Journal, 50(1), 149-174. doi: 10.5465/amj.2007.24162092

4. Cokley K. (2003). What do we know about the motivation of African American students? Challenging the anti-intellectual myth. Harvard Educational Review, 73(4), 524-558. doi: 10.17763/haer.73.4.3618644850123376

5. Deci E.L., Ryan R.M. (2008). Self-determination theory: A macro theory of human motivation, development, and health. Canadian Psychology/Psychologie canadienne, 49(3), 182-185. doi: $10.1037 / \mathrm{a} 0012801$

6. Gibson D.M., Dollarhide C.T., Moss J.M. (2010). Professional identity development a grounded theory of transformational tasks of new counselors. Counselor Education and Supervision, 50(1), 21-38. doi: 10.1002/j.1556-6978.2010.tb00106.x

7. Martin A.J. (2016). The Motivation and Engagement Workbook (16 ${ }^{\text {th }}$ ed.). Sidney, Australia: Lifelong Achievement Group.

8. Moss J.M., Gibson D.M., Dollarhide C.T. (2014). Professional identity development: a grounded theory of transformational tasks of counselors. Journal of Counseling \& Development, 92(1), 3-12. doi: 10.1002/j.1556-6676.2014.00124.x

9. Pintrich P.R., Zusho A. (2002). The development of academic self-regulation: the role of cognitive and motivational factors. In A. Wigfield, J.S. Eccles (Eds.), Development of achievement motivation. San Diego, CA: Academic Press, 249-284. doi: 10.1016/B978-012750053-9/50012-7

10. Roberts L.M., Dutton J.E., Spreitzer G.M., Heaphy E.D., Quinn R.E. (2005). Composing the reflected best self-portrait: Building pathways for becoming extraordinary in work organizations. Academy of Management Review, 30(4), 712-736. doi: 10.5465/amr.2005.18378874

11. Ryan R.M., Deci E.L. (2000). Intrinsic and Extrinsic Motivations: Classic Definitions and New Directions. Contemporary Educational Psychology, 25(1), 54-67. doi: 10.1006/ceps.1999.1020

12. Ryan R.M., Deci E.L. (2002). An overview of Self-determination Theory: An organismic-dialectical perspective. In E.L. Deci, R.M. Ryan (Eds.), Handbook of self-determination research. 3-33. Rochester, NY: The University of Rochester Press.

13. Vaivade-Kalnmeiere L., Mārtinsone K., Ḷevina J. (2016). Supervizoru profesionālā identitāte: pilotpētijuma rezultāti [Professional identity of supervisors: results of pilot study]. Retrieved from https://www.rsu.lv/sites/default/files/imce/Dokumenti/prezentacijas/supervizoru_profesionala_identitate.pdf (in Latvian)

14. Vignoles V.L., Regalia C., Manzi C., Golledge J., Scabini J. (2006). Beyond self-esteem: Influence of multiple motives on identity construction. Journal of Personality and Social Psychology, 90(2), 308-333. doi: 10.1037/0022-3514.90.2.308

15. Wasityastuti W., Susani Y.P., Prabandari Y.S., Rahayua G.R. (2018). Correlation between academic motivation and professional identity in medical students in the Faculty of Medicine of the Universitas Gadjah Mada Indonesia. Educación Médica, 19(1), 23-29. doi: 10.1016/j.edumed.2016.12.010

16. Wigfield A., Eccles J.S. (Eds.). (2002). Development of achievement motivation. San Diego, USA: Academic Press. Retrieved from https://www.elsevier.com/books/development-of-achievementmotivation/wigfield/978-0-12-750053-9

17. Woo H., Henfield M.S. (2015). Professional Identity Scale in Counseling (PISC): Instrument Development and Validation. Journal of Counselor Leadership and Advocacy, 2(2), 93-112. doi: 10.1080/2326716X.2015.1040557 